\title{
Thyroid Function Test, C- Reactive Protein And Blood Lipids In Subclinical Hypothyroidism Patients Reporting At Surgical Wards
}

\author{
Summaya Qazi, Khalil Ahmed Almani, Rizwanullah Junaid Bhanbhro
}

ABSTRACT:

Objective: To investigate the thyroid function, C-reactive protein (CRP) and blood lipid profile in the subclinical hypothyroidism (SH) patients in surgical wards and outpatient department.

Study design: Cross sectional study

Place and Duration: Department of surgery, Isra University Hospital from August 2014 to May 2017.

Materials and Methods: 100 subclinical hypothyroid cases and 100 controls were included according to inclusion and exclusion criteria. Serum TSH level $>6.2(\mu \mathrm{IU} / \mathrm{ml})$ with normal free $\mathrm{T}_{4}$ and $\mathrm{T}_{3}$ was considered as subclinical hypothyroidism. Venous blood was taken from ante cubital vein, centrifuged and processed. Sera were used for the assay of thyroid hormones, TSH, blood lipids and C-reactive protein. Data variables were analyzed by Statistix 8.0 (95\% confidence interval) ( $P$-value $=0.05$ ).

Results: Age in controls and cases was noted as $51.3 \pm 12.5$ and $50.8 \pm 11.95$ years respectively. SH cases show serum $\mathrm{T}_{3}, \mathrm{~T}_{4}$ and TSH as $0.89 \pm 0.18 \mu \mathrm{g} / \mathrm{dl}, 4.96 \pm 0.85 \mu \mathrm{g} / \mathrm{dl}$ and $11.95 \pm 2.85 \mu \mathrm{U} / \mathrm{ml}$ respectively. Serum total cholesterol, triglycerides and LDLc were raised with concomitant low HDLc in SH cases. C- reactive protein in SH cases was $6.91 \pm 3.38 \mathrm{ng} / \mathrm{ml}$ compared to controls $2.56 \pm 1.51 \mathrm{ng} / \mathrm{ml}(\mathrm{P}=0.0001)$. Serum TSH showed negative correlation with $\mathrm{HDLC}$, serum $\mathrm{T}_{3}$ and $\mathrm{T}_{4}$.

Conclusion: The present study reports dyslipidemia with elevated inflammatory marker of C-reactive protein in subclinical hypothyroid patients.

Key words: Subclinical hypothyroidism, Dyslipidemia, C-reactive protein

\section{INTRODUCTION:}

Low normal thyroid function with minimal or no clinical symptoms is termed as subclinical hypothyroidism (SH). ${ }^{1}$ It is biochemical rather than clinical diagnosis, characterized by raised thyroid stimulating hormone (TSH) levels, normal free T4 and asymptomatic patients. Raised TSH is a response to the decreased secretory capacity of thyroid gland this clinical entity is defined as $\mathrm{SH}^{2}$ with few or no symptomatic characteristics of hypothyroidism. Absence of clinical symptoms is a hallmark of $\mathrm{SH} .{ }^{3}$ There are many cases of hypothyroidism which fall into the category of SH being very common among female subjects. ${ }^{4,5}$ Thyroid function tests show normal free thyroxin (FT4) and triiodothyronine (T3) in the presence of raised serum TSH. ${ }^{6}$ Dyslipidemia is a most common metabolic abnormality in hypothyroidism, similar may be the problem in the SH. Dyslipidemia is

I Sumayya Qazi

Assistant Professor, Department of Biochemistry

Isra University, Hyderabad

Khalil Ahmed Almani

I Assistant Professor,

I Isra University Hospital, Hyderabad

I Rizwanullah Junaid Bhanbhro

I Assistant Professor, Department of Surgery

Isra University Hospital, Hyderabad

I Received: 30-01-18

Revised: 20-02-18

Accepted: 10-03-18 characterized by raised serum low density lipoprotein cholesterol (LDL-c), total cholesterol and triglycerides in the presence of low high density lipoprotein cholesterol (HDL-C), a condition which is considered as proatherogenic. It is speculated that the hypothyroid state causes low expression of LDLc receptors on liver cells. This casues defective removal of LDLc from blood, the result is a hyper-LDLc in blood. ${ }^{7}$ This is still debatable and just a speculation. In $\mathrm{SH}$, such metabolic abnormality does occur or not is debatable, as previous studies ${ }^{8,9}$ reported no changed in blood lipids. However, other studies ${ }^{10,11}$ reported dyslipidemia is evident in patients suffering from SH. Dyslipidemia is pro-atherogenic condition in itself with a tendency of ischemic coronary atherosclerotic disease. This needs further studies to gather the information. Dyslipidemia plays role in the pathogenesis of atherosclerosis and related vascular disorders, this may particularly be more dangerous in the SH patients. ${ }^{11} \mathrm{C}$-reactive protein (CRP) is one of reliable inflammatory markers. CRP is known future predictors of atherosclerosis related vascular disease. ${ }^{12}$ CRP has been used as risk factor for the coronary artery disease (CAD).$^{13} \mathrm{CRP}$ with dyslipidemia may be more creative in predicting the vascular disorders in SH patients. However, some of previous studies ${ }^{13,14}$ have produced conflicting results on the dyslipidemia and CRP in SH. Many cases of thyroid swellings present in the surgical wards and outpatient departments with abnormal thyroid function test. 
The present case control study was conducted to determine the lipid profile and C-reactive protein of subclinical hypothyroid cases at our tertiary care hospital.

\section{SUBJECTS AND METHODS:}

The present case control study was conducted at the Department of surgery, Isra University Hospital after ethical approval was taken. The study covered duration from August 2014 to May 2017. Over the study duration, many cases of thyroid lesions were evaluated for the inclusion and exclusion criteria. Finally, a sample of 100 cases of subclinical hypothyroidism ( $\mathrm{SH}$ ) was isolated for the study. Subjects were selected by non- probability purposive sampling. Subclinical hypothyroidism was defined as serum TSH $>6.2 \mu \mathrm{IU} / \mathrm{ml}\left(\right.$ normal serum $\mathrm{T}_{4}$ and $\left.\mathrm{T}_{3}\right) .{ }^{15}$ Age $>20$ and $<50$ years and both male and female were included. Diagnosed cases of overt hypothyroidism were strictly excluded. Patients taking thyroxine therapy, pregnant women, diabetics, systemic hypertension and those smoking were also excluded. Age and gender matched controls were also inducted. Cases and control subjects were interviewed. Confidence was taken by informing them about the purpose of study. They were informed that the study will cause no harm or financial burden on them. The participants were informed that the study needs biodata, physical examination and blood samples for biochemical analysis. Willing participants were further asked that they can ask any issue if they are thinking of it about any financial loss or physical harm. Volunteers were asked to sign the research consent form. Complete biodata and findings of physical examination were noted. Thyroid gland was examined. Systemic blood pressure was checked by mercury sphygmomanometer and body weight on weighing scale. Information was noted in a pre- structured designed proforma. This was followed by blood sampling. Ante-cubital fossa was sterilized with alcohol swab. Tourniquet was applied above cubital fossa to engorge the veins. $10 \mathrm{ml}$ venous blood was taken from ante- cubital vein. Sera were separated by blood centrifugation (3000 rpm for 10 minutes). Thyroid function test (TSH, $\mathrm{T}_{3} \& \mathrm{~T}_{4}$ ) and C-reactive protein (CRP) were assayed by ELISA assay kit. Lipids were analysed on chemistry analyzer using standard methods while LDLc was estimated by Friedewald's formula. ${ }^{16}$ Signing consent form was mandatory. A structured proforma was used for data collection. Data variables were analyzed on Statistix 8.0. Continuous and categorical data variables were analysed by Student's t-test and Chi square test respectively at $95 \%$ confidence interval ( $\mathrm{P}$-value $=0.05$ ).

\section{RESULTS:}

Mean \pm SD age of controls and cases was $51.3 \pm 12.5$ and $50.8 \pm 11.95$ years respectively. Body weight, BMI, Systolic $\mathrm{BP}$ and Diastolic BP showed statistically non- significant differences between controls and cases. Cases showed serum $\mathrm{T}_{3}, \mathrm{~T}_{4}$ and TSH as $0.89 \pm 0.18 \mu \mathrm{g} / \mathrm{dl}, 4.96 \pm 0.85 \mu \mathrm{g} / \mathrm{dl}$ and $11.95 \pm 2.85 \mu \mathrm{U} / \mathrm{ml}$ respectively. These were found statistically significant compared to controls $(\mathrm{P}=0.0001)$. Serum total cholesterol and triglycerides were raised in cases while HDLc was found low. C- reactive protein in cases was $6.91 \pm 3.38 \mathrm{ng} / \mathrm{ml}$ compared to controls $2.56 \pm 1.51 \mathrm{ng} / \mathrm{ml}(\mathrm{P}=0.0001)$ (table 1). Serum TSH showed negative correlation with $\mathrm{HDLC}$, serum $\mathrm{T}_{3}$ and $\mathrm{T}_{4}$ as shown in table 2.

\begin{tabular}{|l|c|c|c|}
\hline & Controls & Cases & P-value \\
\hline Age (years) & $51.3 \pm 12.5$ & $50.8 \pm 11.95$ & 0.76 \\
\hline Body weight $(\mathrm{kg})$ & $76.3 \pm 10.89$ & $71.4 \pm 14.53$ & 0.108 \\
\hline BMI $\left(\mathrm{kgm}^{-2}\right)$ & $29.87 \pm 3.65$ & $29.21 \pm 2.78$ & 0.71 \\
\hline Systolic BP $(\mathrm{mmHg})$ & $120.9 \pm 10.5$ & $120.5 \pm 9.80$ & 0.83 \\
\hline Diastolic BP $(\mathrm{mmHg})$ & $76.6 \pm 11.5$ & $77.5 \pm 10.55$ & 0.96 \\
\hline Serum $\mathrm{T}_{3}(\mu \mathrm{g} / \mathrm{dl})$ & $0.91 \pm 0.17$ & $0.89 \pm 0.18$ & 0.001 \\
\hline Serum $\mathrm{T}_{4}(\mu \mathrm{g} / \mathrm{dl})$ & $5.45 \pm 2.35$ & $4.96 \pm 0.85$ & 0.0001 \\
\hline Serum $\mathrm{TSH}(\mu \mathrm{U} / \mathrm{ml})$ & $3.81 \pm 1.12$ & $11.95 \pm 2.85$ & 0.0001 \\
\hline Total Cholesterol $(\mathrm{mg} / \mathrm{dl})$ & $193.5 \pm 16.5$ & $237.5 \pm 11.5$ & 0.0001 \\
\hline Triglycerides $(\mathrm{mg} / \mathrm{dl})$ & $198.5 \pm 9.5$ & $409.5 \pm 27.5$ & 0.0001 \\
\hline LDL-cholesterol $(\mathrm{mg} / \mathrm{dl})$ & $99.0 \pm 21.5$ & $173.5 \pm 11.5$ & 0.0001 \\
\hline HDL-cholesterol $(\mathrm{mg} / \mathrm{dl})$ & $41.7 \pm 5.5$ & $33.9 \pm 10.5$ & 0.0001 \\
\hline C- reactive $\mathrm{protein}(\mathrm{ng} / \mathrm{ml})$ & $2.56 \pm 1.51$ & $6.91 \pm 3.38$ & 0.0001 \\
\hline
\end{tabular}

Table 1. Demographic and laboratory findings of study subjects 


\begin{tabular}{|l|c|c|}
\hline & r-value & P- value \\
\hline $\mathrm{CRP}(\mathrm{ng} / \mathrm{dl})$ & $0.616^{* *}$ & 0.0001 \\
\hline Cholesterol & $0.813^{* *}$ & 0.0001 \\
\hline $\mathrm{HDLC}$ & $-0.316^{* *}$ & 0.0001 \\
\hline $\mathrm{LDLC}$ & $0.671^{* *}$ & 0.0001 \\
\hline Serum $\mathrm{T}_{3}$ & $-0.275^{* *}$ & 0.0001 \\
\hline Serum $\mathrm{T}_{4}$ & $-0.339^{* *}$ & 0.0001 \\
\hline
\end{tabular}

**. Correlation is significant at the 0.01 level (2-tailed)

Table 2. Pearson`s correlation of serum thyroid stimulating hormone (TSH)

\section{DISCUSSION:}

The present study observed statistically significant differences of T3, T4, TSH, blood lipids and CRP between controls and SH cases $(\mathrm{P}<0.05)$. This is the first study being reported form Surgical wards of a tertiary care hospital. The null hypothesis was rejected as significant difference was noted between the controls and SH cases. Mean \pm SD age of controls and cases was $51.3 \pm 12.5$ and $50.8 \pm 11.95$ years respectively. Body weight, BMI, Systolic BP and Diastolic BP showed statistically non- significant differences between controls and cases. These findings are in agreement with previous studies. ${ }^{17-19} \mathrm{SH}$ cases showed very high serum TSH $(11.95 \pm 2.85 \mu \mathrm{U} / \mathrm{ml})$ with normal $\mathrm{T}_{3}$ and $\mathrm{T}_{4}$, the finding is in keeping with a recent study. ${ }^{20}$ Serum TSH showed negative correlation with total cholesterol, LDLc, HDLc, serum $\mathrm{T}_{3}$ and $\mathrm{T}_{4}$ and CRP (table 2) in SH cases. Serum TSH showed significant rise in $\mathrm{SH}$ cases with dyslipidemia. The $\mathrm{CRP}$ is a risk factor for the coronary artery disease (CAD) ${ }^{17}$ myocardial infarction (MI) ${ }^{18}$ and rheumatoid arthritis (RA) ${ }^{19}$ which is found high in SH cases in the present study. High CRP has been reported in overt hypothyroidism ${ }^{21}$ the finding is consistent with the present study. In present study, serum total cholesterol, triglycerides and LDLc were raised with low HDLc, this is in contrast to previous studies. ${ }^{21,22}$ However, other studies ${ }^{23,24}$ had reported dyslipidemia similar to the present study. A previous study ${ }^{25}$ reported low HDLc in hypothyroidism that is in agreement to present study. In present study, the C- reactive protein in cases was raised i.e. $6.91 \pm 3.38 \mathrm{ng} / \mathrm{ml}$ compared to controls $2.56 \pm 1.51 \mathrm{ng} / \mathrm{ml}(\mathrm{P}=0.0001)$ (table 1$)$. CRP is raised in inflammatory conditions. ${ }^{26,27}$ Raised CRP of present study is in agreement with a previous study. ${ }^{28}$ The findings indicates the subclinical hypothyroidism (SH) is associated with dyslipidemia and raised CRP which is a marker of inflammatory process. Serum TSH reveals positive correlation with $\mathrm{CRP}(\mathrm{r}=0.616, \mathrm{p}=0.0001)$ which is agreement with a recent study. ${ }^{20}$ The HDLc, serum $\mathrm{T}_{3}$ and $\mathrm{T}_{4}$ showed inverse correlation with TSH in subclinical hypothyroid cases (Table 2). These findings are in agreement with previous studies. ${ }^{29-31}$ The finding of dyslipidemia with raised CRP in subclinical hypothyroid cases is consistent with another previous study ${ }^{32}$ which had reported similar observations. A previous study ${ }^{33}$ the dyslipidemia with raised levels of high sensitivity CRP (hs-CRP) is a consistent risk factor for coronary artery disease in subclinical hypothyroid cases. Raised CRP levels in subclinical hypothyroid patients of present study is in concordance with another previous study. ${ }^{34}$ The present study shows the subclinical hypothyroid patients are at increased risk of developing coronary artery disease and related vascular complications. Hence it is suggested the subclinical hypothyroid patients presenting at surgical wards and outpatient departments should be screened for the dyslipidemia and C-reactive protein for timely intervention in order to halt atherosclerotic pathologies. This will help prevent atherosclerosis and related morbidities in subclinical hypothyroid patients.

\section{CONCLUSION:}

It is concluded that the subclinical hypothyroidism is associated with dyslipidemia and inflammatory process. These patients should be screened for timely intervention for preventing the atherosclerosis related coronary artery disease. Further large scale studies are warranted to make guideline on dyslipidemia in subclinical hypothyroid patients for future prevention.

\section{REFERNCES:}

1. Ufion AA, Zulfiqar B, Hassan A, Habibi R, Boddu P. Subclinical Hypothyroidism and Its Association with increased Cardiovascular Mortality. Cardiol Res Prac 2017; Article ID 7539735:1-5.

2. Marchiori RC, Pereira LAF, Naujorks AA, Rovaris DL, Meinerz DF, Duarte MMF, et al. Improvement of blood inflammatory marker levels in patients with hypothyroidism under levothyroxine treatment. BMC End Dis 2015; 15 (32):1-9.

3. Mohamed GA, Elsayed AM. Subclinical hypothyroidism ups the risk of vascular complications in type 2 diabetes. Alexandria J Med 2017; 53; 285-288.

4. Turemen EE, Cetinarslan B, Sahin T, Canturk Z, Tarkun I. Endothelial dysfunction and low grade chronic inflammation in subclinical hypothyroidism due to autoimmune thyroiditis. Endocr J 2011; 58(5):349-54.

5. Bilgir O, Bilgir F, Calam M, Calam OG Yuksel A. Comparison of pre- and post-levothyroxine high-sensitivity c-reactive protein and fetuin-a levels in subclinical hypothyroidism. Clinics 2015;70:97-101

6. Deshmukh V, Behl A, Iyer V, Joshi H, Dholye JP, Varthakavi PK. Prevalence, clinical and biochemical profile of subclinical hypothyroidism in normal population in Mumbai. Indian J Endocrinol Metab 2013; 17(3):454-59.

7. Shekhar R, Chowdary NVS, Das MC, Vidya D, Prabodh S. Prevalence of subclinical hypothyroidism in coastal Andhra Pradesh. Biomedical Research 2011; 22(4):471-44. 
8. Wang CY, Chang TC, Chen MF. Associations between subclinical thyroid disease and metabolic syndrome. Endocrine J 2012; 59(10):911-17.

9. Park YJ, Lee EJ, Lee YJ, Choi SH, Park JH, Lee SB, et al. Subclinical hypothyroidism (SCH) is not associated with metabolic derangement, cognitive impairment, depression or poor quality of life (QoL) in elderly subjects. Arch Gerontol Geriatr 2010; 50(3):68-73.

10. Hak AE, Pols HA, Visser TJ, Drexhage HA, Hofman A, Witteman JC. Subclinical hypothyroidism is an independent risk factor for atherosclerosis and myocardial infarction in elderly women: the Rotterdam Study. Ann Int Med 2000; 132(4):270-78.

11. Libby P. Inflammation in atherosclerosis. Arterioscler Thromb Vasc Biol 2012; 32:2045-51.

12. Lowe GD. Circulating inflammatory markers and risks of cardiovascular and non- cardiovascular disease. J Thromb Haemost 2005; 3(8):1618-27.

13. Ridker PM. C- reactive protein - A simple test to help predict risk of heart attack and stroke. Circulation 2003;108(12):81-85.

14. Yu YT, Ho CT, Hsu HS, Li CI, Davidson LE, Liu CS. Subclinical hypothyroidism [15] is associated with elevated high sensitive C-reactive protein adult Taiwanese. Endocrine 2013; 44(3):716-22.

15. Chawla R. Practical clinical biochemistry methods and interpretation. Jaypee Brothers India. $3^{\text {rd }}$ Ed 2008: 277 79

16. Burtis CA, Ashwood ER, Bruns DE. Teitz fundamentals of clinical chemistry. Saunders An imprint of Elsevier. $6^{\text {th }} \mathrm{Ed}$ 2010: 422-24.

17. Erhardt JG, Estes JE, Pfeiffer CM, Biesalski HK, Craft NE. Combined measurement of ferritin, soluble transferring receptor, retinol binding protein, and C-reactive protein by an inexpensive, sensitive, and simple sandwich enzymelinked immunosorbent assay technique. J Nutr, 2004; 134(11):3127-32.

18. Christ-Crain M, Meier C, Guglielmetti M, Huber PR, Riesen W, Staub JJ, Muller B. elevated C-reactive protein and homocysteine values: cardiovascular risk factors in hypothyroidism? A cross-sectional and a double blind, placebo-controlled trial. Atherosclerosis, 2003; 166(2):37986.

19. Calorabo P, Golia E, Yeh ET. Role of C reactive protein in acute myocardial infarction and stroke: possible therapeutic approaches. Curr Pharm Biotechnol. 2012; 13(1):4-16.

20. Mala S, Kumar S, Piryanka K, Shaikh ZA. Serum inflammatory markers in subclinical hypothyroidis. Eur J Pharma Med Res 2017;4(9): 855-859.

21. Ridker PM, Hennekens CH, Burning JE, Rifai N. C-reactive protein and other markers of inflammation in the prediction of cardiovascular disease in women. New Engl J Med. 2000; 342(12):836-43.
22. Arikan S, Bahceci M, Tuzcu A, Celik F, Gokalp D. Postprandial hyperlipidemia in overt and subclinical hypothyroidism. Eur J Intern Med. 2012; 23(6):e141-45.

23. Ujwal Upadya B, Suma MN, Srinath KM, Prashant A, Doddamani P, Sv S. Effect of insulin resistance in assessing the clinical outcome of clinical and subclinical hypothyroid patients. J Clin Diagn Res. 2015; 9(2):1-4.

24. Sridevi A, Vivekanand B, Giridhar G, Mythili A, Subrahmanyan KA. Insulin resistance and lipid alterations in subclinical hypothyroidism. Indian J Endocrinol Metab, 2012; 16(Suppl 2):S345-46.

25. Kvetny J, Heldgaard PE, Bladbjerg EM, Gram J. Subclinical hypothyroidism is associated with a lowgrade inflammation, increased triglyceride levels and predicts cardiovascular disease in males below 50 years. Clin Endocrinol (Oxf), 2004; 61(2):232-38.

26. Erdem TY, Ercan M, Ugurlu S, Balci H, Acbay O, Gundogdu S. Plasma viscosity, an early cardiovascular risk factor in women with subclinical hypothyroidism. Clin Hemorheol Microcirc, 2008; 38(4):219-25.

27. Ford ES. Body mass index, diabetes, and c reactive protein among U.S. adults. Diabetes Care, 1999; 22:1971-77.

28. Ridkar PM, Rifai N, Rose L. Comparison of c reactive protein and low density lipoprotein cholesterol levels in the prediction of first cardiovascular events. NEngJ Med, 2002; 347:1557-65.

29. Roy S, Banerjee U, Dasgupta A. Effect of Sub clinical hypothyroidism on $\mathrm{C}$ reactive protein and ischemia modified albumin. Mymensingh Med J 2015; 24(2):37984.

30. Karoli R, Fatima J, Shukla V, Chandra A, Khanduri S, Rawat A. hospital based study of carotid intima media thickness and high sensitivity C-reactive protein in young hypothyroid patients. JIACM 2014; 15(2):116-19.

31. Mahto M, Chakraborthy B, Gowda SH, Kaur H, Vishnoi G, Lali P. Are hsCRP levels and LDL/ HDL Ratio Better and Early Markers to Unmask Onset of Dyslipidemia and Inflammation in Asymptomatic Subclinical Hypothyroidism? Ind J Clin Biochem 2012; 27(3):284-89.

32. Sharma R, Sharma TK, Kaushik GG, Sharma S, Vardey SK, Sinha M. Subclinical hypothyroidism and its association with cardiovascular risk factors. Clin Lab 2011; 57(910):719-24.

33. Duntas LH, Wartofsky L. Cardiovascular risk and subclinical hypothyroidism: focus on lipids and new emerging risk factors. What is the evidence? Thyroid 2007; 17(11):107584.

34. Xiang GD, Pu J, Sun H, Zhao L, Yue L, Hou J. Regular aerobic exercise training improves endothelium-dependent arterial dilation in patients with subclinical hypothyroidism. Eur J Endocrinol 2009; 161(5):755-61 